Valeria Rosito'

'Universidade Federal Rural do Rio de Janeiro, Instituto Multidisciplinar, Departamento de Letras, Seropédica, RJ, Brasil

\title{
"Avisem-me se eu começar a me tornar eu mesma demais": Lispector nos anos de chumbo
}

Resumo: Estas considerações integram trabalho mais amplo sobre a experiência das configurações identitárias de gênero nos anos de chumbo no Brasil. As crônicas semanais de Clarice Lispector, publicadas no Jornal do Brasil, de meados dos anos 1960 até início dos anos 1970, lançam luz sobre os processos de formação de subjetividades contra o quadro repressivo por parte do Estado totalitário de então. Sua pena atravessa os tênues limites entre o ficcional e o não ficcional, sempre no risco da emergência do estranho (Sigmund FREUD, 1976), elemento básico à dinâmica de gênero no jogo literário.

Palavras-chave: Clarice Lispector; gênero; ficção; crônicas

\section{O ficcional no noticioso: Clarice no jornal}

A estreia de Clarice Lispector como colunista no Caderno B do Jornal do Brasil em 19 de agosto de 1967, lança luz sobre um retrato de época simultaneamente produtor e produto de uma estética nova, e, talvez por isso, polêmica ainda nos nossos dias. "Hermética" e/ou "alienada" são apenas dois dos mais recorrentes qualificativos - não raro rejeitados publicamente pela escritora- relativos à sua escrita. Não foram poucas as vezes em que Clarice endereçou a pecha. Para ficarmos somente nos limites das crônicas em tela, uma delas intitulada exatamente "Hermética? ", gaba-se de ter ganhado o troféu criança-1967 com o livro O Mistério do Coelho Pensante e reflete: "Fiquei contente, é claro. Mas muito mais contente ainda ao me ocorrer que me chamam de escritora hermética. Como é? Quando escrevo para crianças, sou compreendida, mas quando escrevo para adultos fico difícil?" (LISPECTOR, 1984, p.68) Ainda sobre o endereçamento, ou sua falta, por sua pena das questões "sociais", a escritora também replica, numa entrevista:

\section{(c) ()}

Esta obra está sob licença Creative Commons. 
Perguntou-me o que eu achava da literatura engajada. Achei válida. Quis saber se eu me engajaria. Na verdade sinto-me engajada. Tudo o que escrevo está ligado, pelo menos dentro de mim, à realidade em que vivemos. É possível que este meu lado ainda se fortifique mais algum dia. Ou não? Não sei de nada. Nem sei se escreverei mais. É possível que não. (LISPECTOR, 1984, p. 49)

E reforça, posteriormente, quando de outra entrevista sobre o mesmo ponto:

- Você sente e participa dos problemas da vida nacional?

- Como brasileira seria de estranhar se eu não sentisse e não participasse da vida do meu país. Não escrevo sobre problemas sociais mas eu os vivo intensamente e, já em criança, me abalava inteira com os problemas que via ao vivo. (LISPECTOR, 1984, p.68)

Embora seja notória a passagem pregressa de Clarice Lispector pelo jornalismo, é de se ressaltar a insistência da escritora, nas crônicas de que tratamos, em discriminar a oposição entre tal escrita e aquela estritamente ficcional. Logo em uma de suas primeiras crônicas, em 9 de setembro, a cronista confidencia que embora tivesse trabalhado na imprensa como profissional, o teria feito "sem assinar. Assinando, porém, fico automaticamente mais pessoal. E sinto-me um pouco como se estivesse vendendo minha alma." (LISPECTOR, 1984, p. 12). Pontifica ainda em "Ser Cronista", malgrado possamos Ihe atribuir a criação de uma persona nas perguntas que lhe brotam, que deveria conversar com Rubem Braga, o inventor da crônica, a esse respeito:

Crônica é um relato? É uma conversa? É o resumo de um estado de espírito? Não sei, pois antes de começar a escrever para o Jornal do Brasil, eu só tinha escrito romances e contos. Quando combinei com o jornal escrever aqui aos sábados, logo em seguida morri de medo. Um amigo que tem voz forte, convincente e carinhosa, praticamente intimou-me a não ter medo. Disse: escreva qualquer coisa que lhe passe pela cabeça, mesmo tolice, porque coisas sérias você já escreveu, e todos os seus leitores hão de entender que a sua crônica semanal é um modo honesto de ganhar dinheiro. (LISPECTOR, 1984, p. 108)

Desse momento até 29 de dezembro de 1973 - aquela que veio a se celebrizar como um dos mais cultuados nomes do olimpo modernista da geração de 1945, passa a travar com o gênero crônica e com a mídia jornalística um embate declaradamente pouco confortável para si, mas bastante revelador de seu processo criativo marcantemente desafiador das tradições estabelecidas por gênero/sexualidade. A respeito do lugar de Clarice naquela geração, Silviano Santiago nos lembra, numa citação de autoria de Ernst Bloch, de como, naqueles anos 1940 e junto com Guimarães Rosa, a escritora inaugurara "uma elaboração concreta do espanto que sentimos diante do próprio mundo", espanto esse que advém não "do ser, propriamente, mas da latência do vir-a-ser em ação, os sinais e a prefiguração do ser futuro" (SANTIAGO, 2004, p. 236). Atirada em um circuito de comunicação de massa aberto a leitores rápidos e 'interativos' e confrontada pelas convenções de um gênero que lhe é desconhecido, a artífice da metalinguagem, romancista e contista de enredos frouxos ou inexistentes, deve dar forma assídua e regular à coluna dos sábados por seis anos. Afinal, conforme recorrentes confidências da escritora, desde suas primeiras histórias, aos sete anos, no Recife, era-lhe impossível a obediência aos padrões convencionais dos gêneros ficcionais pelos quais se aventurava:

Eu as enviava para a página infantil das quintas-feiras do Jornal de Recife, e nenhuma, mas nenhuma mesmo, foi jamais publicada. E, mesmo então, era fácil ver por quê. Nenhuma contava propriamente uma história com os fatos necessários a uma história. Eu lia as que eles publicavam, e todas relatavam um acontecimento. (LISPECTOR, 1984, p. 449) 
Faz também pilhéria a respeito de seu "fracasso" quanto a tais convenções, quando as ensaia (ou finge ensaiá-las), em "Um caso para Nelson Rodrigues":

Pois é.

Cujo pai era amante, com seu alfinete de gravata, amante da mulher do médico que tratava da filha, quer dizer, da filha do amante, e todos sabiam, e a mulher do médico pendurava uma toalha branca na janela significando que $o$ amante podia entrar ou era toalha de cor e ele não entrava.

Mas estou me confundindo toda ou é o caso que é tão enrolado que, se puder vou desenrolar, se bem que Dalton Trevisan narraria com o poder maior que tem. As realidades dele são inventadas. Peço desculpas, porque além de contar os fatos, eu também adivinho e o que adivinho aqui escrevo. Eu adivinho a realidade. Mas esta história não é de minha seara. É da safra de quem pode mais que eu. (LISPECTOR, 1984, p. 501)

E finaliza a tentativa com a demarcação de sua diferença em relação aos colegas:

"O que fazer desta história? Também não sei, dou-a de presente a quem quiser, pois estou enjoada dela. Demais até. Às vezes me dá enjoo de gente. Depois passa e fico de novo toda curiosa e atenta. É só." (LISPECTOR, 1984 , p. 503)

Mais relevantemente, as tensões desse mesmo processo criativo, que se deixa capturar na dimensão 'utilitária' e referencial da escrita jornalística, traduzem índices estéticos significativos à luz de uma perspectiva de gênero, aliados a alterações substanciais na economia de trocas do quadro macro político e institucional. Os seis anos em que Clarice Lispector atua como colunista do JB - sobretudo a partir de 1968 - os anos de chumbo - são testemunho de repressão política brutal, em que os limites entre o eu e o não-eu eram lanhados a ferro e a fogo.

Na suposta transição entre a intervenção militar de 1964 e o retorno ao governo civil democrático, algumas das manchetes da edição de estreia da coluna em 1967, emolduram tal quadro. A do editorial "Revolução particular", avalia o "primeiro impasse" do governo Costa e Silva a propósito da derrubada do prefeito de Nova Iguaçu e da "pressa" na derrubada do governador de Mato Grosso (JORNAL DO BRASIL, 19/08/1967, p.6). Divide espaço com o setor internacional, onde se anuncia em caracteres garrafais que os "EUA proclamam direito de intervir no hemisfério" (JORNAL DO BRASIL, 19/08/1967, p.8). Da mesma forma, a nota "censura ao DCT [Departamento de Correios e Telégrafos]" (LISPECTOR., 1984, p.32) noticia a violação legal, amparada por decreto-lei, de pacotes com publicações importadas por universidades, consideradas "por autoridades competentes" "pornográficas" ou "atentatórias à Segurança Nacional" (LISPECTOR., 1984, p.32).Se a pena feminina areja partes do jornal à época, é exclusivamente masculina a autoria em circuito dos mais vendidos/lidos, seja no horizonte da ficção ou da não ficção em língua portuguesa e estrangeira. Além de Lispector na coluna de estreia, Gilda Chataignier registra em "A pílula e a fábula: os caminhos do vácuo", preocupações sociais com o uso generalizado - por dezesseis anos desde seu advento - da pílula anticoncepcional. A "autoridade competente" entrevistada, neste caso, o médico Campos da Paz, presidente do Conselho Mundial de Fertilidade, refuta as preocupações da jornalista sobre o vácuo geracional cogitado por ela, pontificando que "a mulher só se realiza psico-sexualmente, quando se transforma em mãe. Nem que seja numa maternidade parcial, como no caso da adoção. Ela só assim amadurece, sente-se realmente mulher" (CHATAIGNIER, 19/08/1967, Caderno B, p. 28).

O esboço da cena político-social no debut de Lispector no Jornal do Brasil de 19/08/ 1967, flagra o "sujeito moderno" em sua indeterminação, e ilumina o momento contemporâneo pelo avesso, em se tratando de configurações identitárias levadas ao paroxismo nas formas multiplicadas de fundamentalismos. No caso de nossa escritora, os 
rumos da 'emancipação' feminina se entrechocam, na América Latina, por um lado, fortificados com quadros inegavelmente conservadores e machistas, por outro, pelo crescente arrocho político perpetrado pelo Estado totalitário e repressor. É esse contexto político atravessado por interesses internacionais - em que se espraiam anúncios inquietantes de aniquilação de todo e qualquer não-eu - que nos convida a defender a índole visceralmente resistente e opositiva da escrita clariceana, testemunho da fundação de uma nova ficção em que crônica e literatura perdem suas fronteiras no emaranhado de fios de seda:

Avisem-me se eu começar a me tornar eu mesma demais. É minha tendência. Mas sou objetiva também. Tanto que consigo tornar o subjetivo dos fios de aranha em palavras objetivas. Qualquer palavra, aliás, é objeto, é objetiva. Além do mais, fiquem certos, não é preciso ser inteligente: a aranha não é, e as palavras não se podem evitar. Vocês estão entendendo? Nem precisam. Recebam-me apenas como eu estou dando. Recebamme com fios de seda. (Lispector, 17/05/1969, Caderno B, p. 2)

Sua tenacidade na configuração do eu como inexoravelmente imbricada em um vasto rol de alteridades, nos permite desenvolver a hipótese de que sua "A experiência maior", título de uma de suas crônicas de 06 de novembro de 1971, se plenifica na passagem do eu ao outro, reconhecido significativa e necessariamente como um outro eu .Esse outro eu, afeito à dúvida e à indeterminação, lhe custou, não raro, acusações relativas à sua alienação política, acusação que acaba por se estender à ancoragem de gênero de sua escrita. No entanto, não seria a contínua dúvida do eu, ao invés, um libelo feminista contra o macro contexto autoritário, essencialista e sexista?

Seria imprecisa a postulação de um resultado afeito à síntese dialética em Clarice, a partir da tensão entre opostos, ao modo do idealismo hegeliano. Sua oscilação traduz a tendência para a solução não conciliatória dos extremos; ou seja, para a permanência da tensão, como realidade última. A ressalva teórica nos parece particularmente proveitosa à tentativa de definir a inserção desta Clarice Lispector contra o quadro político de sua época. Diante desse retrato, a discussão se ocupa de um conjunto de suas crônicas, publicadas, posteriormente, em formato de livro com o título $A$ descoberta do mundo (1984), em cujos polos se situam identidades humanas e não humanas, em um continuum complexo de indeterminações do eu a um outro eu. No espaço intervalar, identidades reconhecíveis por gênero, circunscrição diastrática, etária, racial, entre outras, são desfamiliarizadas, enquanto que o desconhecido se torna, incomodamente, familiar. São trazidas às luzes considerações teóricas de Sigmund Freud, no ensaio O estranho, de 1919, assim como parte da produção filosófica de Nietzsche, aos existencialistas contemporâneos de Clarice Lispector. Os referenciais teóricos nos parecem particularmente fecundos diante das condições histórico-contextuais de sua emergência - a crescente xenofobia deflagradora do fascismo e do nazismo na Europa de fins do século XIX; a sequência de duas guerras mundiais devastadoras, até meados do século $\mathrm{XX}$; as ditaduras latino-americanos nos anos 1960-70's e, finalmente, a escalada global dos fundamentalismos no período póscolonial contemporâneo.

\section{A "experiência maior": o estranho no humano e o humano no estranho}

"Eu antes tinha querido ser os outros para conhecer o que não era eu. Entendi então que já tinha sido os outros e isso era fácil. Minha experiência maior seria ser o âmago dos outros e o âmago dos outros era eu." (LISPECTOR, 06/11/1971, Caderno B, p. 2). 
O Estranho, ensaio de Freud datado de 1919, se lança sobre a base semântica da língua alemã para conceituar heimlich, usualmente uma designação para 'doméstico' e 'familiar'. No entanto, a mesma forma positiva do termo porta intrigante ambivalência conceitual:

O que mais nos interessa nesse longo excerto é descobrir que, entre os seus diferentes matizes de significado, a palavra 'heimlich' exibe um que é idêntico ao seu oposto, 'unheimlich'. Assim, o que é heimlich vem a ser unheimlich. (Cf. a citação de Gutzkow: 'Nós os chamamos 'unheimlich'; vocês o chamam 'heimlich.") Em geral, somos lembrados de que a palavra 'heimlich' não deixa de ser ambígua, mas pertence a dois conjuntos de idéias que, sem serem contraditórias, ainda assim são muito diferentes: por um lado significa o que é familiar e agradável e, por outro, o que está oculto e se mantém fora da vista. (FREUD, 1976, p. 5)

É significativo, na citação, que os contrários não se excluem, sendo sua coexistência, portanto, não só geradora da tensão própria da 'experiência de estranhamento', mas também resultante final não conciliatório das tendências contrárias. Adicionalmente, o pensador insiste em distinguir o horrível e o assustador do estranho, embora os dois efeitos não se obriguem à mútua exclusão. Segundo Freud, embora mais conhecida pela definição do Belo, a natureza da arte é inextricável de sua afeição ao estranho. Valendo-se da cena ficcional, como lhe é comum, Freud sustenta que a aceitação da fantasia por parte do leitor/ouvinte do conto de fadas em momento algum responde por sensações semelhantes àquelas causadas pela experiência com o estranho. Esta última desafia os "testes de realidade" e não se equivale ao impasse causado meramente por incertezas intelectuais. O teórico sugere ainda que o mesmo 'fato', como u'a mão decepada, por exemplo, pode deflagrar experiências diversas no leitor/ouvinte - mas não necessariamente a da ordem do estranho:

Já perguntamos [ver em [1]] por que é que a mão decepada na história do tesouro de Rhampsinitus não tem o estranho efeito que a mão cortada tem na história de Hauff. A questão parece ter crescido em importância, agora que reconhecemos que a categoria de estranho, oriunda de complexos reprimidos, é a mais resistente das duas. A resposta é fácil. Na história de Heródoto, os nossos pensamentos estão muito mais concentrados na astúcia superior do chefe dos ladrões, do que nos sentimentos da princesa. A princesa pode muito bem ter tido uma sensação estranha, na verdade provavelmente caiu desmaiada; mas nós não temos tal sensação, pois nos colocamos no lugar do ladrão, e não no lugar dela. (FREUD, 1976, p. 28) [grifos acrescentados]

Torna-se decisivo para o efeito de estranhamento, segundo se infere das palavras do ensaísta, uma dose significativa de simpatia - na narrativa ficcional obtida por meio da técnica de fazer coincidir o ponto de vista do leitor/ouvinte com a do personagem em questão. Tomar o lugar do outro ou reconhecer a si no outro parece satisfazer condições preliminares para a experiência do estranho. Seu movimento letal se traduz como o esquecimento/recalque do que já foi conhecido, portanto familiar, em retorno como um híbrido perturbador, "como uma fonte enterrada ou um açude seco", capaz de gerar "a sensação de que a água vai brotar de novo." (GUTZKOW, apud FREUD, 1976, p. 4). A ambiguidade do uso das duas formas do termo - a positiva e a negativa - arremata a fala do personagem: "Oh, nós chamamos a isso 'unheimlich'; vocês chamam 'heimlich'. (FREUD, 1976, p. 28).

Sobre a genealogia e os efeitos deletérios desse paulatino 'esquecimento' do nãoeu por meio de sua domesticação ou aniquilamento, Friedrich Nietzsche já elogiava em 1878, o tratamento contrário dado pelos gregos ao seu "demasiado humano": 
Talvez não haja nada mais surpreendente para quem considera o mundo grego do que descobrir que os gregos davam a todas as suas paixões e maus pendores naturais, de tempo em tempo, como que festas e até mesmo instituíram estatalmente uma espécie de ordenamento de celebrações de seu demasiado-humano: é isto o propriamente pagão de seu mundo, que a partir do cristianismo, não é nunca compreendido, não pode nunca ser compreendido e é sempre combatido e desprezado do modo mais duro. - Eles tomavam esse demasiado-humano como inevitável e preferiam, em vez de insultá-lo, dar-lhe uma espécie de direito de segunda classe, ordenando-o dentro dos usos da sociedade e do culto: aliás, tudo o que tem potência no homem eles denominavam divino, e o inscreviam nas paredes de seu céu. (NIETZSCHE, 1983, p. 136)

A passagem ressalta a amplitude do conceito de 'divino' como tudo o que é humano, ao contrário do pensamento excludente em que humano e divino não somente se polarizam como também se excluem; portanto, trata-se também de reconhecer a densidade conceitual de 'humano' na horizontalidade com o divino, mais do que em estratificação hierárquica vertical:

O não grego no cristianismo. - Os gregos não viam os deuses homéricos acima de si, como senhores, e não se viam abaixo deles, como servos, ao modo dos judeus. Viam como que apenas a imagem em espelho dos exemplares de sua própria casta que melhor vingaram, portanto um ideal, não um contrário de sua própria essência. Há o sentimento de parentesco recíproco, subsiste um interesse de lado a lado, uma espécie de simaquia. (NIETZSCHE., 1983, p. 102-103)

A recepção à alteridade, ao não eu- seja ele divino ou humano - se manifesta por meio de seu reconhecimento e culto. O ordenamento dos "maus pendores" não parece se confundir com o desejo de sua domesticação ou, menos ainda, com sua negação, pois "concedia-se ao mal e ao suspeito, ao animalesco retrógrado assim como ao bárbaro, prégrego e asiático que vivia ainda no fundo da essência grega, uma descarga moderada, e não se procurava seu total aniquilamento" (NIETZSCHE, 1983, p. 137). Entende-se como e por que a sensibilidade poética é elogiada pelo filósofo em sua avaliação dos golpes desferidos contra "os espíritos livres", por força do progressivo culto à Razão:

- De onde tiram os gregos essa liberdade, esse sentido do efetivo? Talvez de Homero e dos poetas anteriores a ele; pois precisamente os poetas, cuja natureza não costuma ser a mais justa e mais sábia, possuem em compensação esse gosto pelo efetivo, pelo eficiente de toda espécie, e não querem negar totalmente nem mesmo o mal: bastaIhes que ele se modere e não fira mortalmente ou envenene interiormente tudo - isto é, pensam de modo semelhante aos gregos fundadores de Estados e foram seus mestres e precursores. (NIETZSCHE, 1983, p. 137)

Empobrecimento do humano por meio do rebaixamento e contenção das paixões e consequente edificação de identidades essencializadas são fundamentos com que esses dois pensadores nos brindam para a revisão mais radical da metafísica e do cristianismo, tendo em vista suas relações com a filosofia socrática. Como vimos, formulações sobre 'o que se é' golpeiam o humanismo embasado em uma 'natureza humana 'una e essencial, anterior,em positivo, e, em consequência, determinante das demais 'naturezas vivas', ou 'do que não se é', por processos variados de exclusão, esquecimento, purificação ou "recalque", nos termos freudianos.

Guardadas as diferenças teóricas, filosóficas e epistemológicas na expressão daqueles pensadores e a sistematização do existencialismo por Sartre, interessa-nos, em arremate teórico, que a formação do imaginário clariceano é caudatária de atmosfera de insegurança, acalorada com os resultados devastadores da escalada do fascismo e do 
nazismo. O coup de grâce desferido sobre as filosofias de base metafísica e essencialista presume incerta a natureza do homem, desprendida, definitivamente de qualquer exterioridade/anterioridade que lhe possa socorrer - Deus, por exemplo. Os instrumentais da nova doutrina filosófica, como nas reflexões antecedentes aqui destacadas, investem na reformulação do humanismo moderno e contemporâneo, uma vez que suas formas arrogantes e certezas positivas e científicas redundam em crimes contra a humanidade, testemunhados desde a aurora do século XX:

O existencialista nunca irá considerar o homem como um fim porque ele está sempre se construindo. Nem deveríamos crer que há uma humanidade que devamos cultuar, à maneira de Auguste Comte. O culto à humanidade termina no humanismo autocontido de Comte, e, que seja dito, no fascismo. Podemos passar sem esse tipo de humanismo. (SARTRE, 1965, p. 69)

Ressalte-se a qualificação sartreana do humanismo em crise - "autocontido", ou seja, aquele que se afastou de referências externas, ou melhor, segregou - em suposta purificação - um 'interior' de um 'exterior' e se auto definiu como um fim em si mesmo. É abissal a distância, conforme evocado por Nietzsche, entre esse culto ao humano asséptico e o culto dos antigos gregos ao humano 'impuro' conforme já observado. Sublinhe-se que a solidão de sua liberdade, de saber-se sem o deus que lhe aponte caminhos, não implica ao homem, necessariamente, inação diante da corrosão da cena moderna, pois, ainda com o pensador francês, o existencialismo é otimista no sentido de ser uma doutrina de ação (SARTRE, 1965, p. 70):

Essa conexão entre a transcendência, como elemento constituinte do homem - não no sentido em que Deus é transcendente, mas no sentido de ultrapassagem - e a subjetividade, no sentido em que o homem não está fechado em si mas está sempre presente no universo humano, é o que chamamos de humanismo existencialista. Humanismo porque lembramos ao homem que não há legislador outro que não ele próprio, e que em seu estado de abandono ele tomará as decisões por si; porque ressaltamos que o homem realizar-se-á como homem, não voltando para si próprio, mas buscando uma meta do lado de fora de si, o que é justamente essa liberação, exatamente essa particular realização. (SARTRE, 1965, p. 70)

Ao ser "condenado à liberdade", na síntese mais célebre do existencialismo cunhada por Sartre, o homem se torna integralmente responsável por sua ação e inação, pois ambas são consequentes. O pertencimento responsável do homem em um mundo cujos valores "não estão escritos no céu", não pode senão provocar dúvidas em Clarice, diante de qualquer caminho que tome e lhe exigir espanto constante e magnificado diante do mundo:

Hão de me perguntar por que tomo conta do mundo: é que nasci assim, incumbida. $\mathrm{E}$ sou responsável por tudo o que existe, inclusive pelas guerras e pelos crimes de leso-

\footnotetext{
${ }^{1}$ Tradução minha do trecho em inglês: "The existentialist will never consider man as an end because he is always in the making. Nor should we believe that there is a mankind to which we might set up a cult in the manner of Auguste Comte. The cult of mankind ends in the self-enclosed humanism of Comte, and, let it be said, of fascism. This kind of humanism we can do without."

${ }^{2}$ Tradução minha do trecho em inglês: "This connection between transcendency, as a constituent element of man - not in the sense that God is transcendent, but in the sense of passing beyond - and subjectivity, in the sense that man is not closed in on himself but is always present in a human universe, is what we call existentialist humanism. Humanism, because we remind man that there is no lawmaker other than himself, and that in his forlornness he will decide by himself; because we point out that man will fulfill himself as man, not in turning toward him- self, but in seeking outside of himself a goal which is just this liberation, just this particular fulfillment."
} 
corpo e lesa-alma. Sou inclusive responsável pelo Deus que está em constante cósmica evolução para melhor. (LISPECTOR, 1984, p. 298)

Estendendo a Clarice Lispector o comentário de Fredric Jameson sobre Ernst Bloch, Silviano Santiago pontua: "o que espanta [...] não é o ser propriamente, mas a latência do vir-a-ser em ação, os sinais e a prefiguração do ser futuro." (SANTIAGO, 2004, p. 236). Nesse sentido, a experiência do estranho, conforme elaborado por Freud, nos parece elo oportuno para aproximar a plenificação do eu na conexão com o não-eu como uma operação de vir-a-ser às avessas, tendo em vista que o que foi reprimido primordialmente fora, um dia, parte do ser - humano ou demasiado humano.

\section{A cronista, as crianças e os bichos, "uma das formas acessíveis de gente"}

$$
\begin{aligned}
& \text { Ofélia perguntou devagar, com recato pelo que the acontecia } \\
& \text { - É um pinto? } \\
& \text { Não olhei para ela. } \\
& \text { - É um pinto, sim. }
\end{aligned}
$$

O trecho que se dá à epígrafe acima integra a "noveleta" em cinco partes, publicadas durante todo o mês de agosto de 1969, uma pérola da prosa clariceana. Em uma de suas inesperadas, porém costumeiras visitas à escritora, a vizinha Ofélia, menina impertinente, de afetos contidos, é flagrada, a despeito de seus esforços ao contrário, em sua criancice inelutável. O móvel? Um pio fraco, mas audível, soado da cozinha da escritora. Entre a menina que dá e vem à luz em seu ser-menina, a escritora, - como sua 'parteira 'extremosa cuidando para não "brutaliza-la"-, e o ser-pinto, que deflagra e participa da metamorfose vital, o leitor/a é dragado para a dimensão microscópica do espaço-tempo 'quântico' da narrativa. O labor estético - literal e ambivalentemente, um 'trabalho de parto' - que torna possível a captura do pulsar ínfimo da mutação -é dotação inaugural da atomização do tempo na prosa, ou da espacialização da narrativa (SANTIAGO, 2004, p. 236). Por meio do adensamento do instante, a escritora dá à luz ao que antes estava interditado aos leitores (SANTIAGO, 2004, p. 237) e realiza, assim, uma ação emancipatória, de alta relevância ao exercício pleno da sexualidade feminina.

Na repetição exaustiva de significantes - "pinto", "pinto", "pintinho", "pintinho", "pintinho", "pintinho" - o relance do real - aqui compassado pela percussão onomatopaica, que lança o "pinto em si" para a menina-pinto, menina-menina, escritora-menina, escritorapinto e escritora-escritora - todos libertos de seus grilhões e interdições, simultaneamente parturientes e paridos:

A agonia de seu nascimento. Até então eu nunca vira a coragem. A coragem de ser o outro que se é, a de nascer do próprio parto, e de largar no chão o corpo antigo. E sem Ihe terem respondido se valia a pena. "Eu", tentava dizer o corpo molhado pelas águas. Suas núpcias consigo mesma. (LISPECTOR, 1984, p. 241)

No protagonismo dessa captura, se figura "tudo o que grita e pulula", ou ecoando Nietzsche, tudo o que tem potência. Entre tais formas de ser, as crônicas em tela privilegiam 
o deslize entre o que se é e o que não se é: "Mais e mais se deformava, quase idêntica a si mesma." (ibid.). Se o caso permite reivindicar a correlação entre o humano, o não humano e o mais humano, sem dúvida levanta a questão de que humano falamos quando a plenitude do ser(humano) é emblematicamente subtraída do feminino. Em "A princesa", ressalta-se no tempo de ser-menina, uma variante de gênero tautológica no contexto externo repressor do ser-mulher:

Ali, diante de meu silêncio, ela estava se dando ao processo, e se me perguntava, tinha que ficar sem resposta. Tinha que se dar - por nada. Teria que ser. E por nada. Ela se agarrava em si, não querendo. Mas eu esperava. Eu sabia que nós somos aquilo que tem que acontecer. Eu só podia servir-lhe a ela de silêncio. E deslumbrada de desentendimento, ouvia bater dentro de mim um coração que não era o meu. Diante de meus olhos fascinados, ali, diante de mim, como um ectoplasma, ela estava se transformando em criança. (LISPECTOR, 1984, p.241)

Decoupado em sua 'saturação de agoras' (BENJAMIN, 1994), o tempo-espaço permite inusitadas formas prismáticas de organização do ponto de vista da narrativa que, em pulsação, faz convergir os lugares de observadora e observada: "Ouvia bater dentro de mim um coração que não era o meu." (LISPECTOR, 1984, p.241). Explorada com fartura nas crônicas, a criança se torna emblema de estágios avançados de liberdades em sexualidades historicamente reprimidas.. Fundamental elemento de realização do 'parto' na noveleta 'Princesa', a cronista tem relevância variada como personagem em suas crônicas. Não deixa de laborar, no entanto, com especial maestria, em todos os flagrantes dos tempos quânticos em que se desenrolam as sensações de suas personagens. São esses os elementos orquestrados em "O Intransponível", não ao acaso organizado em torno do feminino também. Sob a lente da cronista em uma rua, uma menina ruiva, em espera não se sabe de que ou de quem, encontra-se "com sua outra metade neste mundo":

[...] Era um basset lindo e miserável, doce sob sua fatalidade. Era um basset ruivo. Lá vinha ele trotando, à frente de sua dona, arrastando seu comprimento. Desprevenido, acostumado, cachorro.

A menina abriu os olhos pasmados. Suavemente avisado, o cachorro estacou diante dela. Sua língua vibrava. Ambos se olhavam.

Entre tantos seres que estão prontos para se tornarem donos de outro ser, lá estava a menina que viera ao mundo para ter aquele cachorro. Ele fremia suavemente, sem latir. Ela olhava-o sob os cabelos, fascinada, séria. Quanto tempo se passava? Um grande soluço sacudiu-a desafiando. Ele nem sequer tremeu. Também ela passou por cima do soluço e continuou a fita-lo.

Os pelos de ambos eram curtos, vermelhos. (LISPECTOR., 1984, p. 264)

No plano de construção textual, essa crônica se realiza somente em modo narrativo, sem recurso a diálogos formais, ao contrário do observado em "A princesa". Como na primeira, no entanto, a retratação de um e de outro personagem central se distribui equanimemente entre descrições alternadas dos dois, abraçadas na comunidade tão visceral quanto é fugaz o encontro entre a "infância impossível" dela e a "natureza aprisionada" dele. Menina e basset se fitam, se entregam e se compreendem num instante congelado. Aqui, a narradora, sem participação direta - a não ser pelos olhares inicialmente cruzados com a menina ruiva - se ocupado disparo fotográfico em flash do que se desdobra em temporalidades ínfimas e vitais. Atravessando situações banais, o acontecimento assim se define, segundo Silviano Santiago, a posteriori (SANTIAGO, 2004, p. 236-7), traduzindo-se como substrato material do que perdura na memória a título de experiência; portanto, a partir de seu caráter iniciático e de seus efeitos transformadores e irrepetíveis: "Ela ficou 
espantada, com o acontecimento nas mãos, numa mudez que nem pai nem mãe compreenderiam." (ibid.). A duração desse instante/eternidade, fato-feito-acontecimento"Quanto tempo se passava?" - é sustentada pela maestria da 'fotógrafa' que interrompe com precisão o fluxo temporal e capta gestos essenciais na revelação espacial do quadro.

\section{IV. "É isso ficção?" - entre a porta da geladeira e as páginas de um livro, uma coisa que arfa}

Outra pessoa que conheço estava hospedada numa casa e foi abrir a porta da geladeira para beber um pouco de água. E viu a coisa.

A coisa era branca, muito branca. E, sem cabeça, arfava. Como um pulmão. Assim: para baixo, para cima, para baixo, para cima. A pessoa fechou depressa a geladeira. E ali perto ficou, de coração batendo.

(LISPECTOR, 29/05/1971, Caderno B, p. 2)

Assinale-se, outra vez, que fora do contexto que torna inteligível a sugestão sobre 'um respeito à nossa violência', podem soar 'alienadas' ou mesmo 'cooptadas' as crônicas da colunista, se tomarmos o fundo político repressor por parte dos Estados sul americanos naqueles dias. 'Subversão' é termo recorrente nos diários e nos discursos oficiais. Prosseguindo com a folheada nas manchetes políticas do sábado em que o recorte epigrafado é publicado (JORNAL DO BRASIL, 29/05/1971, p. 13-17), na vigência do governo de Médici, saltam os casos de perseguição política indiscriminada à sociedade civil. Somente nessas páginas, um religioso no Peru, um estudante, além do advogado de presos políticos, Sobral Pinto, têm sua liberdade ameaçada em função de ações públicas de desacordo com a ordem totalitária vigente. Chamamos à atenção, dessa forma, que o tratamento pela cronista ao humano, em suas interfaces com o estranho, em nada coincide com o distanciamento ou compactuação com qualquer forma de constrangimento à liberdade historicamente situada, como tantas vezes a acusou a crítica 'engajada'. Nem tampouco dilui o feminino sob o véu do humano, uma vez que a cronista ocupa um lugar de enunciação raro, marcado por gênero no jornal em que é chamada a colaborar. Sobre os extermínios programáticos e racionalizados contra formas de vida humana que o século XX experimentava - recentes ainda os ecos de Auschwitz - a cronista revira, nos anos de chumbo no Brasil, as ruínas de um humanismo nefasto desde a sua mais remota invenção pelo homem. Levanta a lupa contra o instrumental sofisticado de reificação do humano e do não humano com o enigma da coisa arfante: sem cabeça ou casco - é isso uma tartaruga, ou somos nós ficção de gênero?:

Depois veio a saber do que se tratava. $O$ dono da casa era perito em caça submarina. E pescara uma tartaruga. E lhe tirara o casco. E lhe cortara a cabeça. E pusera a coisa da geladeira para no dia seguinte cozinha-la e comê-la.

Mas enquanto não era cozida, ela, sem cabeça, nua, arfava. Como um fole. (LISPECTOR, 1984 , p. 380-381)

Essa breve visita aos limites da ficção-crônica pelas mãos de Clarice Lispector encenada contra um quadro de terceiro milênio testemunhal do crescimento de fundamentalismos, genocídios, misoginia e extermínios de não-eus - expõe experiências radicais de estranhamento, inquietação e suspeita sobre todas as certezas; contribui, portanto, para se dimensionarem alguns dos caminhos da crítica feminista como crítica cultural mais ampla, exercida sobre a excessiva espetacularização da realidade, o consumo instantâneo e produção de identidades prêt-a-porter. Em 5 de fevereiro de 1972, a cronista brinca seriamente com a possibilidade de uma encarnação melhor e mais verdadeira, estranhamente relutante em "ser ela mesma demais": 


\section{Eu me arranjaria}

Se o meu mundo não fosse humano, também haveria lugar para mim: eu seria uma mancha difusa de instintos, doçuras e ferocidades, uma trêmula irradiação de paz e luta; se o mundo não fosse humano eu me arranjaria sendo um bicho. Por um instante então, desprezo o lado humano da vida e experimento a silenciosa alma da vida animal. É bom, é verdadeiro, ela é a semente do que depois se torna humano. (LISPECTOR., 1984, p. 447)

E nós, nos arranjaríamos?

\section{Referências}

BENJAMIN, Walter. "Sobre o conceito da história". In: BENJAMIN, Walter. Magia e técnica, arte e política: ensaios sobre literatura e história da cultura. Obras escolhidas, v.1. Trad. Sergio Paulo Rouanet. São Paulo: Brasiliense, 1994, p. 222-232.

CHATAIGNIER, Gilda. "A pílula e a fábula: os caminhos do vácuo", Jornal do Brasil, Rio de Janeiro, 19/08/1967, Caderno B, p. 6-8.

FREUD, Sigmund. "O estranho". In: FREUD, Sigmund. Obras completas. vol. 17. Rio de Janeiro: Imago, 1976. Disponível em https://pt.scribd.com/search-documents?query=o+estranho $\% 2 C+$ FreudAcesso em 30/12/2014.

JORNAL DO BRASIL. Rio de Janeiro. 19/08/1967, "Editorial”, p. 6-8. Disponível em www.jb.com.br/ paginas/news-archive/Acesso em 30/12/2014.

LISPECTOR, Clarice. A descoberta do mundo, Rio de Janeiro: Rocco, 1984. 541 p.

Disponível em http://minhateca.com.br/nonedoubt/Documentos/last+books/LIVROS/ Clarice+Lispector/Clarice+Lispector+-+A+Descoberta+Do+Mundo, 2365784.pdf. Acesso em 10 fev. 2014.

Jornal do Brasil, Rio de Janeiro, 19/08/1967, Caderno B, p. 3. Disponível em https:// news.google.com/newspapers?nid=0qX8s2k 1 IRwC\&dat $=19670819 \&$ printsec $=$ frontpage $\& \mathrm{hl}=$ pt-BR. Acesso em 20/12/2014.

. "Fios de seda". Jornal do Brasil, Rio de Janeiro, 17/05/1969, Caderno B, p. 2. Disponível em https://news.google.com/newspapers?nid=0qX8s2k1 IRwC\&dat=1969051 7\&printsec $=$ frontpage\&hl=pt-BR. Acesso em 20/12/2014.

"A Princesa (IV)". Jornal do Brasil, Rio de Janeiro, 23/08/1969, Caderno B, p. 2. Disponível em https://news.google.com/newspapers?nid=0qX8s2k1 IRwC\&dat=19690823 \&printsec $=$ frontpage\&hl=pt-BR. Acesso em 17/12/2014.

. "Máquina escrevendo". Jornal do Brasil, Rio de Janeiro, 29/05/1971, Caderno B, p. 2. Disponível em https://news.google.com/newspapers?nid=0qX8s2k 1 IRwC\&dat $=1971$ 0529\&printsec $=$ frontpage\&hl=pt-BR Acesso em 30/12/2014.

"A experiência maior". Jornal do Brasil, Rio de Janeiro, 06/1 1/1971, Caderno B, p. 2. Disponível em https://news.google.com/newspapers?nid=0qX8s2k1 IRwC\&dat=19711106 \&printsec $=$ frontpage\&hl =pt-BR. Acesso em 20/09/2014

NIETZSCHE, Friedrich. "Humano, demasiado humano: um livro para espíritos livres". In: NIETZSCHE, Friedrich. Obras incompletas; seleção Gérard Lebrun; trad. e notas Rubens Rodrigues Torres Filho; posfácio Antônio Candido. 3.ed. São Paulo: Abril Cultural (Série Os Pensadores), 1983, p. 83-151.

SANTIAGO, Silviano. "A aula inaugural de Clarice Lispector; cotidiano, labor e esperança". In: SANTIAGO, Silviano. O cosmopolitismo do pobre. Belo Horizonte: UFMG, 2004, p. 232-241.

SARTRE, Jean-Paul. The Philosophy of Existentialism. Edited with a Foreword by Wade Baskin, Philosophical Library, New York, 1965. Disponível em https://pt.scribd.com/read/ $171090871 /$ The-Philosophy-of-Existentialism-Selected-Essays\#. Acesso em 30/12/2014. 
[Recebido em 07/07/2016, reapresentado em 12/01/2018 e aprovado em 07/03/2018]

"Let me Know if I become Excessively my Own Self": Lispector in the Years of Plumb Abstract: These notes integrate a larger scope job on the experience gender identity configurations in the so called the twentieth century "plumb" days in the in Brazil. Clarice Lispector's weekly writings in Jornal do Brasil, from the mid-1960's to the early-1970's shed light upon subjectivity processes under way against a setting of brutal political repression by the totalitarian state then. Her pen trespasses the slight frontiers between fiction and nonfiction, in pursuit of the emergence of the uncanny (Sigmund FREUD, 1976), a basic gender element to literary dynamics.

Keywords: Clarice Lispector; Gender; Fiction; Non-fiction Writing.

Valeria Rosito Ferreira (valeriarosito2@gmail.com) é mestre em Inglês pela State University of New York at Buffalo (1982), doutora em Literatura Comparada, pela Universidade do Estado do Rio de Janeiro (2004) e Professora Adjunta de Literatura Brasileira da Universidade Federal Rural do Rio de Janeiro e membro do GP CNPq GEDIR - Gênero Discurso e lmagem.

(iD) $0000-0003-0956-6927$

12 Revista Estudos Feministas, Florianópolis, 26(3): e45486 